\title{
Problems and Legal Countermeasures of Intellectual Property Rights of Chinese Digital TV
}

\author{
Xiao Liangdong \\ Jingdezhen ceramic university
}

Key words: digital TV; intellectual property; countermeasure analysis

\begin{abstract}
With the development of science and technology, digital TV has become the core content of China's media industry, but affected by many factors, resulting in China's Intellectual property rights of digital $\mathrm{TV}$ has a lot of problems, hindered the development of digital TV. How to strengthen the protection of intellectual property rights of digital TV within the framework of law has become the core content of Chinese Enterprises. This paper mainly analyzes the existing problems of intellectual property protection of digital TV in China, then puts forward the relevant countermeasures, hoping to provide reference for the related personnel.
\end{abstract}

Digital TV is a digital way to complete the collection, production, transmission to the user terminal, the core technology is the channel coding and source coding. From the current development of our country, the intellectual property of digital TV is still not as familiar with the public, the corresponding legal protection awareness is still weak.

\section{An analysis of the present situation of the property right of China's digital TV}

At present, with the development of science and technology, digital TV technology has begun to develop rapidly, and plays an important role in people's daily life. From the analysis of the market environment, digital TV technology and product market competition is intense, in order to occupy a place in the fierce market, and discusses the problem of the digital TV rights began to cause the attention of people.the issue of property rights of digital TV has begun to attract people's attention and discussion.

The United States, Europe and China is the world's three major color TV market, about $50 \%$ of China's TV output are used for export, the United States accounted for about $20 \%$ of China. At this stage, each country according to their own development, developed a digital TV standard. The United States, Argentina, Canada and other countries mainly use the ATSC standard developed by the United States. Singapore, Europe and Australia, they mainly use of the EU DVB-T standard. ISDB-T is mainly used in Japan.

China's National Standard Management Committee has used China's digital television broadcasting system as the national standard, the core technology is TDS-0FDM, multi carrier based, integration of single-carrier technology, and also can be used in mobile TV.

ATSC has already been implemented in the early period, which has created a good development opportunity for China's color TV manufacturing. However, from analog TV to digital TV business opportunities, Korea, Europe and Japan are more competitive than China, the main competitive means is intellectual property. Foreign companies to seize the Chinese market, using the core technology to earn profits way to obtain intellectual property rights, and thus to maintain the monopoly of digital TV; Chinese enterprises developed, once again using the huge way to attack; holding core technology companies, mainly dominated by the alliance monopoly position.

From China's current intellectual property protection, mainly by construction industry associations to improve domestic competitiveness; and the establishment of intellectual property rights in the enterprise, mainly to solve the problem of property disputes, has great difference with foreign companies patent cross the acquisition of technology, their own to win a larger space for development. 


\section{From the perspective of patent law, to promote the development of China's digital TV Countermeasures}

At present, our country patent damage suffered more serious, especially a few years ago the DVD patent. In order to actively respond to the development of China's digital TV barriers, we must use advanced commercial means to solve the problem, at the same time,we must use legal means to defend the interests, strengthen technological innovation and development, break the patent and technical barriers, and then occupy a higher position in the global market. Specific can start from the following aspects.

2.1 Play the role of patent information, build internal patent warning mechanism. Patent information is public information, mainly include the scope of protection, legal information, technical classification information, the applicant information, etc., which is the core material of competitors and the development direction of different industries and technology.Foreign companies in the actual research and development will learn from the open patent information.But from the domestic situation, the current relevant people can not apply the patent information to understand the development of domestic and foreign competitors. Data reports show that more than $95 \%$ of new foreign research and development technology to be patented after the open, but China has fewer patents, it has a great influence of Chinese development of digital TV. The use of patent information, not only can help technical researchers to master the development of competitors, but also can help enterprises to build early warning mechanism. Foreign companies in the publication of patents, must be carried out early warning analysis, to avoid the serious consequences of patent infringement. Therefore, China must play the role of patent information, build a sound early warning mechanism to reduce the impact on enterprise development.

2.2 The implementation of patent strategy, combined with the actual layout of the patent. Patent strategy that enterprises in order to encourage long-term survival in the market environment, mainly from the patent system and function to get more to improve the status of enterprise development strategy. At present, patent issues have become the only way for many enterprises to achieve sustainable development, it can also combine patent strategy analysis technology and market development, and then combined with their own development, to develop a reasonable part of the patent, and continuously improve their market competitiveness and innovation .Due to the different enterprise development scale, way and mode of operation there are large differences, so you can choose different approaches. For enterprises with strong autonomy, must be based on patents as the prerequisite of the development, and constantly improve the development of the market. For follow-type enterprises, can be combined with basic patents, forming a tight peripheral patent protection.At present, the digital television technology of Chinese enterprises have a big gap with foreign countries, and the basic patent is less, so we can refer to the "surround the cities from the countryside", construction of peripheral patent network, continue to break the technical barriers of foreign enterprises, and to create active development. For example, in the actual development, we can actively learning and introduction the introduction of some foreign higher value dependent train, and on the basis of its bold to create. In practice, there is no guarantee that all technologies can be patented, but the continuous improvement of the patent right can be less aggressive than that of the foreign counterparts, thus reducing the impact on the enterprise development technology and providing enterprises with higher market conditions .

2.3 Improve the status of patent standards, build intellectual property system. Intellectual property is a combination of time and region of the patented technology, it has strong adaptability. And at present, many standards have a strong patent, it give strong protection of intellectual property rights in China. The patent requirements, using the standard personal or business, you must pay a fee to the the standard of patent right. At present, with the development of the times, the developed countries have combined with the development needs, established more standard, realize the development of technology to intellectual property in China.

At this stage, many governments in China have been aware of the importance of establishment of intellectual property standards, and combining with the national conditions establish the technical standards of professional, by using the new way to upgrade their industrial interests. At present, the 
state and relevant departments have established the standard working group, it can use standards play a leading industry. Therefore, domestic enterprises should send their patent into standards, and give full play to the role of application in market competition, improve the market competitiveness.

2.4 Other legal measures. First, the legal protection of copyright law. In order to improve the protection of copyright, digital television producer must use vivid detail to express their own ideas, and then get the corresponding copyright. Once a dispute can ensure the stability of the template. If you can combine the events presented in the television program, people, etc. to protect, you can avoid unauthorized monopoly of information. From the professional point of view, the digital TV program idea is worth learning and application, but the script ideas prohibit copying, we must strengthen the legal protection.

Second, the legal protection of contract. Digital TV producers can use legal means to safeguard their rights, obligations and other legitimate rights. Because the structure of digital TV requires a large amount of information, so it has more links, once any one link of leakage of trade secrets, will cause great impact on TV is expected, so must to strengthen the protection of the television program idea. In order to reduce the digital TV program of internal staff and production staff of leakage of important information on the details of the deal, must require employees to sign a confidentiality clause within the first turn. In addition, in order to prevent the relevant personnel to make the similar digital TV program, the parties shall sign a confidentiality agreement in the negotiations.

\section{Concluding remarks}

This paper combined with the development status of domestic digital TV, analyzes the existing problems of intellectual property protection of digital TV in China, combined with the actual situation, puts forward the legal measures, hoping to provide reference for domestic researchers, to protect their own interests, improve the competitive position in the international market, and promote the long-term sustainable development of digital TV.

\section{Reference:}

[1] Peng Zhubin, Yang Mei Yan. Protection and management of intellectual property rights of Chinese TV content industry in digital age [J]. news and communication research, 2009,(05)

[2] Yue Yongjuan, Hu Yaqin. Intellectual property protection of digital TV technology [J]. TV technology, 2013, (06)

[3] Qiao Hong. Research on digital TV standard and intellectual property [J]. information technology and standardization, 2014, (04)

[4] Miao Yunping. Research on the development of digital TV technology under the background of intellectual property [J]. Heilongjiang Science and Technology Information, 2014, (12).

[5] Xu Ruishan. Research on the marketization of digital TV industry in China [J]. Tianjin University, 2014, (04) 